\title{
Utilization of Molecular Quick Test as an Effort to Accelerate Case Findings of Multi Drug Resistant Tuberculosis in South Sulawesi Province
}

\author{
Andi Julia Junus ${ }^{1}$, Abdul Gafur ${ }^{2}$ \\ ${ }^{1,2}$ Department of Public Health, Unversitas Pejuang Republik Indonesia, Makassar, Indonesia \\ Corresponding Author: Abdul Gafur
}

\begin{abstract}
The discovery of TB and MDR TB cases increases every year along with the addition of TCM machines, which currently number 46 machines and have spread across 24 districts/cities in the roadmap towards TB elimination in 2030. This study aims to determine the effectiveness of the use of Molecular Rapid Tests to accelerate the diagnosis of TB and MDR TB in South Sulawesi and to evaluate the utilization of TCM examinations for examination of TB and MDR TB during the Covid 19 pandemic. The method used in collecting TB and MDR TB data is to compile secondary data from several data sources, namely eTB Manager, TCM monthly reports, SITT and SITB. The data that has been collected will be processed and analyzed descriptively and presented in the form of tables and trend charts for 3 years. The number of case discoveries between 2018 and 2019 showed an increase in cases as more suspects were referred for TCM examination. In 2020 the discovery of TB cases has decreased, namely TB RO cases as many as 483 and TB SO cases as many as 7,736 cases. The decline in cases in 2020 was due to the Covid 19 pandemic where many suspects did not want to visit health facilities. The addition of the number of TCM can increase the case finding of TB SO and TB RO which is accompanied by strengthening the specimen referral network system, especially in areas with difficult transportation or remote areas so that the diagnosis of $\mathrm{TB}$, especially $\mathrm{TB}$ with Rifampicin resistance can be found early.
\end{abstract}

Keywords: Molecular Quick Test, Case Findings of Multi-Drug Resistant Tuberculosis

\section{BACKGROUND}

The Tuberculosis (TB) Prevention and Control Program Strategy continues to develop in line with policy changes in TB case finding. The WHO global strategy for the prevention, treatment and control of tuberculosis 2015-2035 known as the End TB Strategy recommends early diagnosis of TB and universal drug susceptibility testing (DST), which underscores the important role of laboratories in the strategy. In this regard, the Indonesian National Tuberculosis Control Program prioritizes the development of a network of TB laboratories using the latest diagnostic tools. The use of TB molecular rapid tests is one of the efforts to speed up diagnosis, so that patients can get treatment as early as possible $^{[1]}$.

TB has become a serious threat that competes with the Human Immunodeficiency Virus (HIV) and currently Indonesia is the country with the second highest TB burden in the world. The World Health Organization (WHO) Global TB Report 2020 estimates TB cases in Indonesia at 845,000 cases and the estimated incidence of cases Tuberculosis Multi-Drug Resistant (MDR) of 24,000 or $8.8 / 100,000$ population. In 2019, about 11,500 RR TB patients were identified and reported, about $48 \%$ of patients starting second-line TB treatment, with a treatment success rate of $45 \%$. Ending the TB epidemic in 2030 is one of the good health targets of the Sustainable Development Goals (SDGs) ${ }^{[2]}$. 
Achievement of the TB program in South Sulawesi based on the results of the evaluation of TB data for 3 years, namely 2017-2019, shows a trend of increasing coverage of case detection and treatment, namely in 2017 there were 17,430 cases $(45 \%)$, in 2018 there were 29,439 cases $(79 \%)$ and in 2019 there were 30,611 cases (99\%). The MDR TB data reported in 2019 showed the number of patients who were examined for TCM as many as 6115 suspects and the result was that the number of patients diagnosed with RO TB was 466 cases and who were willing to undergo treatment 245 cases $(53 \%)^{[3]}$.

The discovery of TB and MDR TB cases increases every year along with the addition of TCM machines, which currently number 46 machines and have spread across 24 districts/cities. In the roadmap towards TB elimination in 2030, one of the intervention packages carried out is screening for groups with high risk of TB and expanding the range of services to people with TB in the community that have not been detected so far by expanding Molecular Rapid Tests in $80 \%$ of suspected TB in 2030. To find out the effectiveness of case finding with the expansion of TCM at several sites, this paper will provide an overview based on data on the trend of finding TB and MDR TB cases for 3 years and TCM utilization during the Covid 19 pandemic. ${ }^{[1]}$

This study aims to determine the effectiveness of the use of Molecular Rapid
Tests to accelerate the diagnosis of $\mathrm{TB}$ and MDR TB in South Sulawesi and to evaluate the utilization of TCM examinations for examination of TB and MDR TB during the Covid 19 pandemic.

\section{METHODS}

The method used in collecting TB and MDR TB data is to compile secondary data from several data sources, namely eTB Manager, TCM monthly reports, SITT and SITB. The data that has been collected will be processed and analyzed descriptively and presented in the form of tables and trend charts for 3 years.

\section{RESULTS}

In graph 1 shows the trend of TCM utilization for 3 years, namely 2018-2020. The number of examinations that have been carried out for 3 years has fluctuated, namely in 2018 there were 21,646 suspects, in 2019 there were 57,834 suspects, and in 2020 there were 38,546 suspects.

In graph 2 shows the number of examination results with MTB results both TB SO and TB RO. The number of case discoveries between 2018 and 2019 showed an increase in cases as more suspects were referred for TCM examination. In 2020 the discovery of TB cases has decreased, namely TB RO cases as many as 483 and TB SO cases as many as 7,736 cases. The decline in cases in 2020 was due to the Covid 19 pandemic where many suspects did not want to visit health facilities.

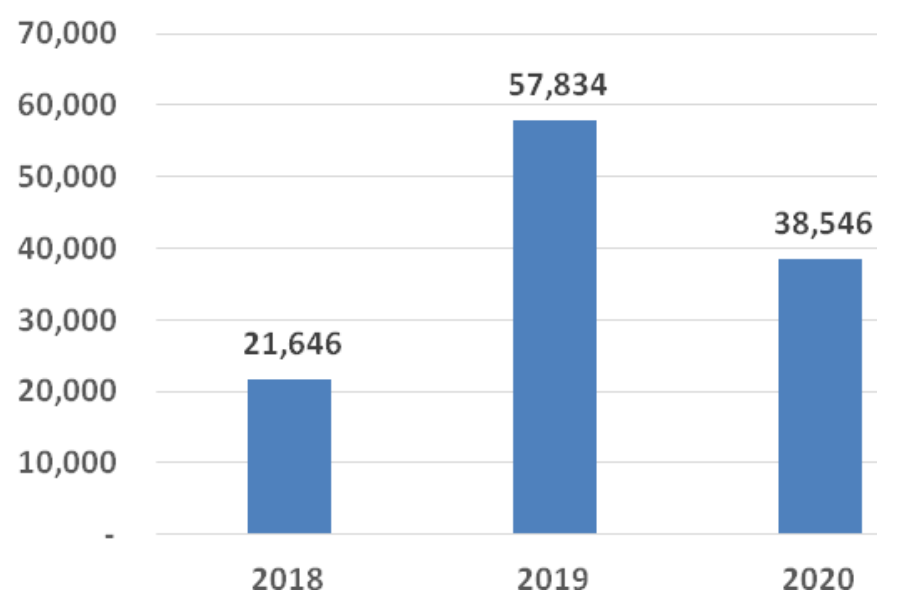

Graph 1. Trends in TCM Utilization of South Sulawesi Province in 2018-2020 
Andi Julia Junus et.al. Utilization of molecular quick test as an effort to accelerate case findings of multi drug resistant tuberculosis in South Sulawesi Province.

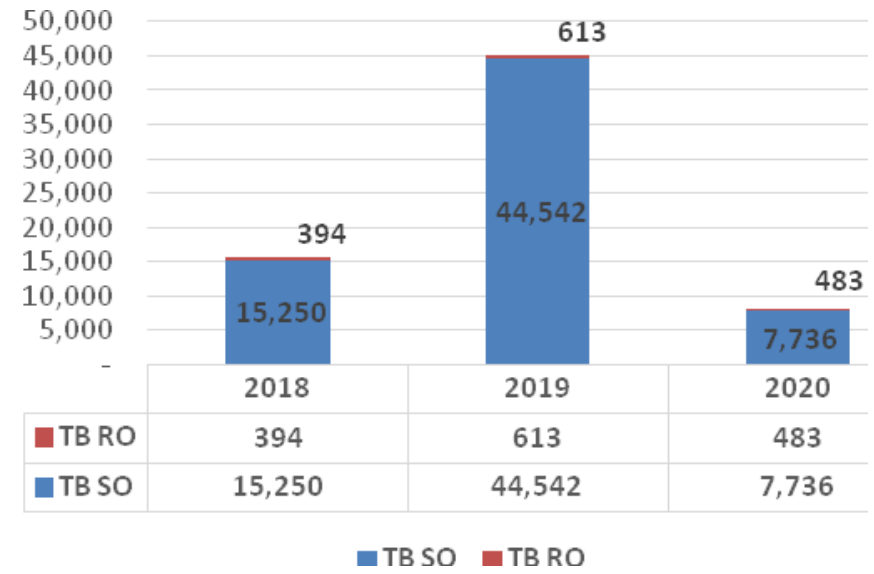

Graph 2. Number of Case Findings for TB SO and TB RO in South Sulawesi Province in 2018-2020

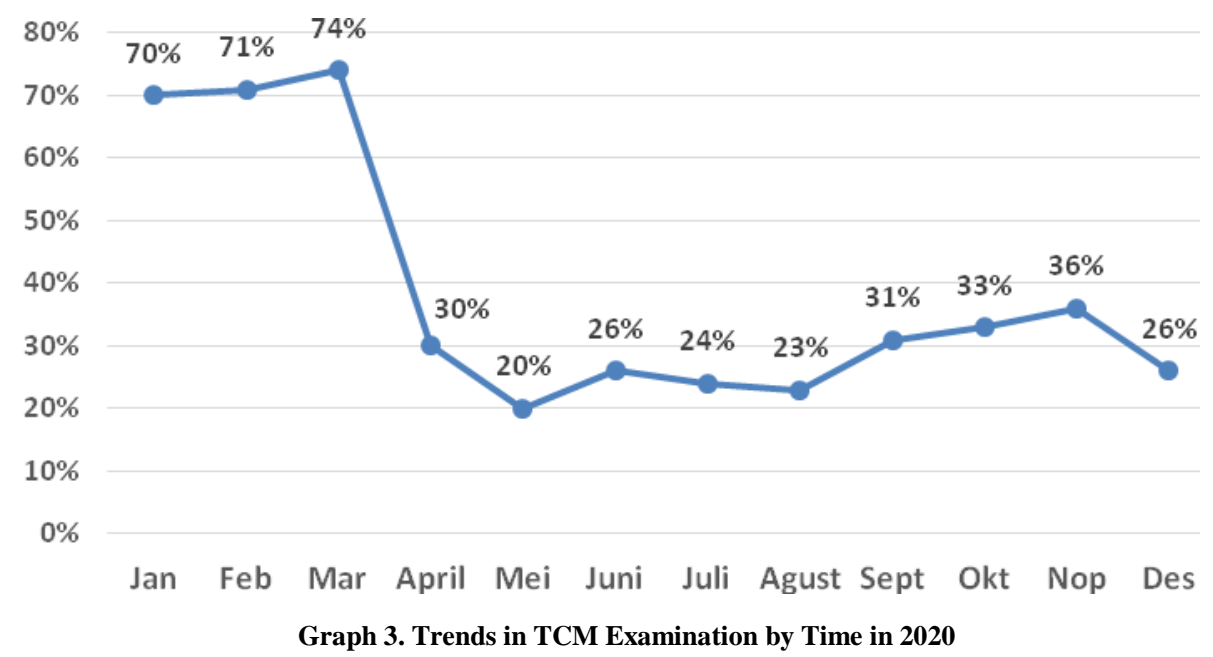

The trend of monthly TCM examinations can be seen in graph 3. The graph shows an increase in inspections in the first quarter with a peak in March of 74\%. In April there was a quite drastic decrease of up to $30 \%$ in line with the Covid 19 pandemic. This condition fluctuated gently until December, which was $26 \%$.

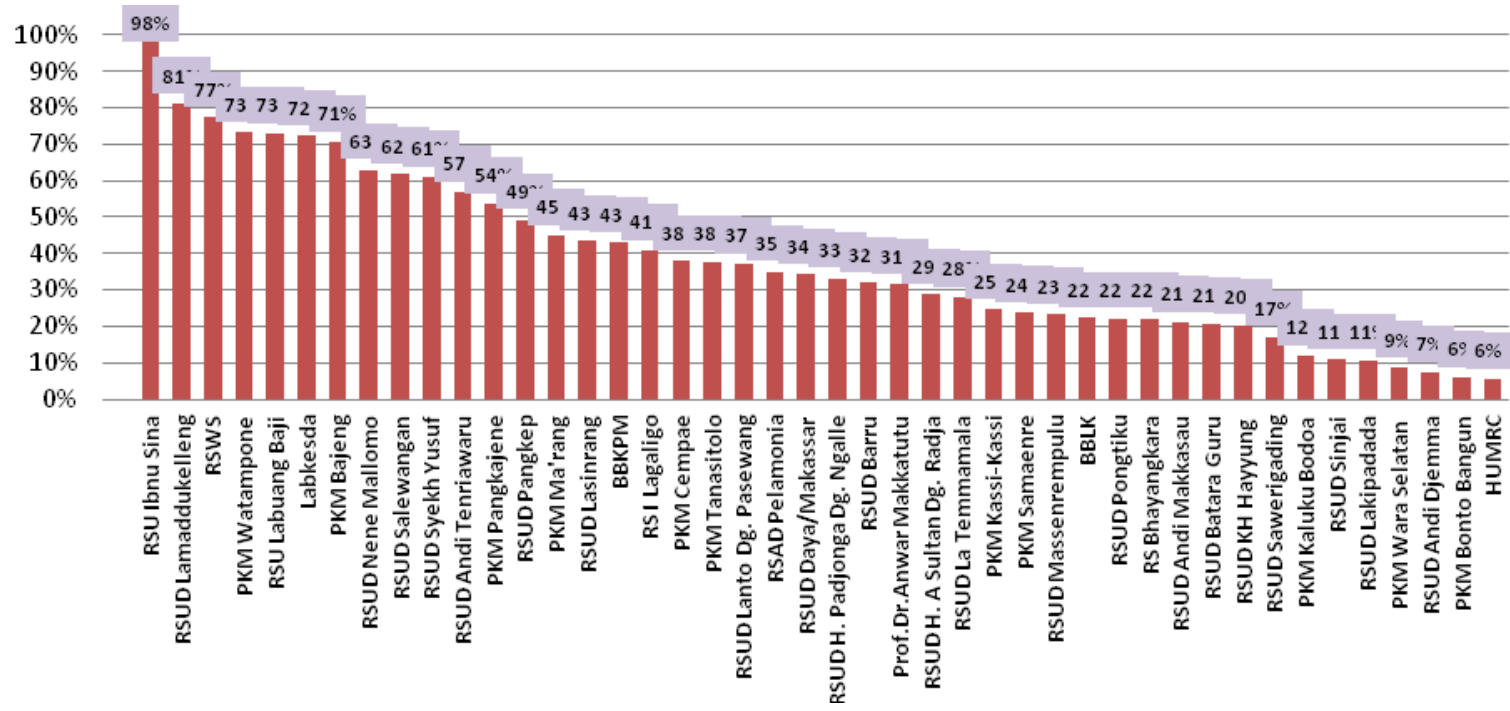

Graph 4. TCM Utilization Based on TCM Laboratories in 2020 

resistant tuberculosis in South Sulawesi Province.

Based on graph 4 , it can be seen that TCM utilization is based on health facilities that carry out TCM examinations. In 2020 the utilization of TCM decreased due to the lack of suspects who were referred to carry out TCM examinations. Of the 43 TCM machines spread across 24 regencies, 3 health facilities with high utilization were found at Ibnu Sina Hospital, Lamaddukelleng Hospital, district Wajo and Dr. Wahidin Sudirohusodo. The health facilities/laboratories with low utilization are HUMRC, Public Health Centre Bonto Bangun and Hospital Andi Djemma.

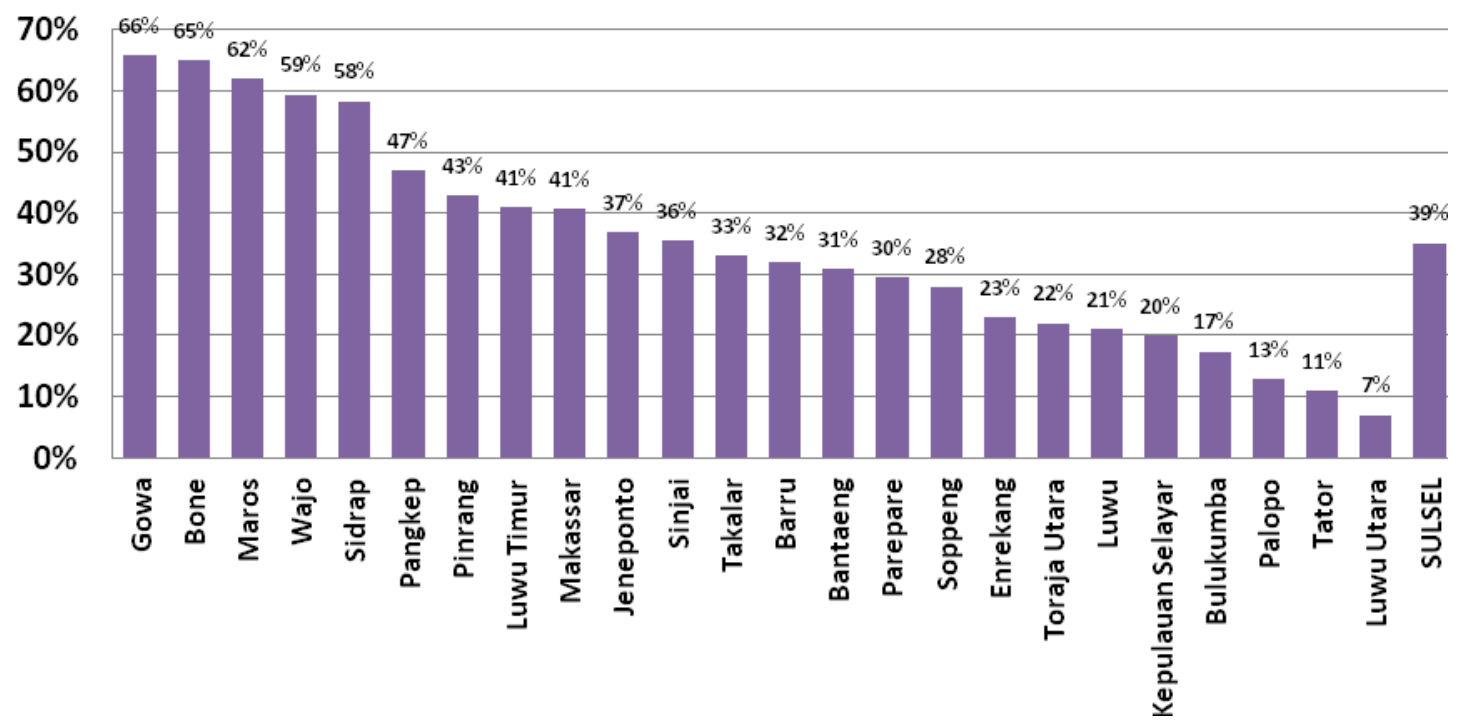

Graph 5. Utilization of TCM in 24 Regencies and Cities in 2020

Utilization of TCM spread across 24 regencies is shown in graph 5. None of the 24 regencies have achieved the $80 \%$ inspection target and the cumulative utilization results for South Sulawesi
Province only reached $35 \%$. The 3 districts with high utilization are Gowa (66\%), Bone $(65 \%)$ and Maros $(62 \%$, while districts with very low utilization are Palopo (13\%), Tator $(11 \%)$ and North Luwu (7\%).

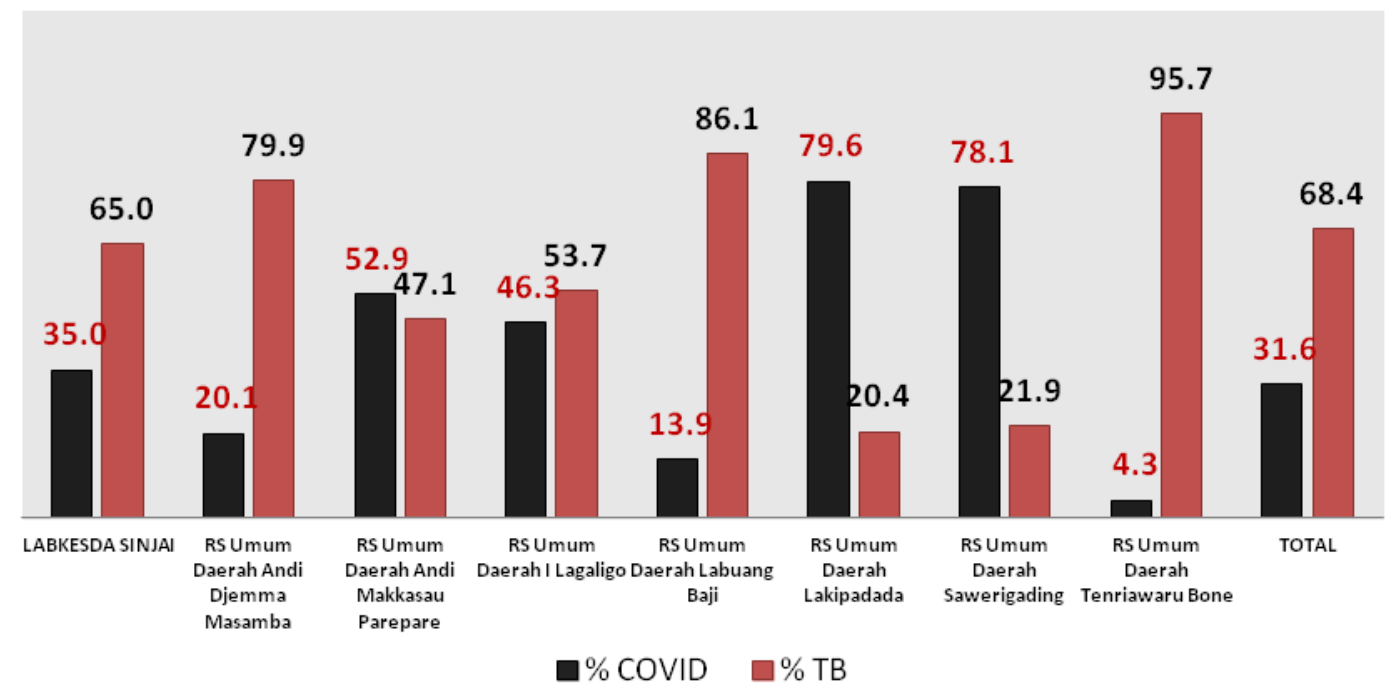

Graph 6. Comparison of TCM Utilization for Tuberculosis and Covid 19 Examinations in South Sulawesi Province in 2020

In graph 6 provides an overview of the comparison in $\mathrm{TB}$ and Covid 19 examinations using the TCM machine. The results show that during 2020 there are still 
more TCM examinations for the TB program compared to covid 19 , but from 8 TCM-Covid 19 health facilities there are 3 health facilities that carry out more TCM Covid 19 examinations, namely Andi Makkasau Hospital, Lakipadada Hospital and Sawerigading Hospital.

\section{DISCUSSION}

Problems of the TB control program are the low case finding and the length of time it takes to establish a TB diagnosis. One of the strategies used to deal with this problem is to conduct contact investigations actively, intensively and massively. This must be accompanied by the readiness of laboratories that are able to detect TB cases quickly, including smear negative cases that are often associated with HIV and increase the capacity of laboratories to diagnose Drug Resistant TB (RO) ${ }^{[3]}$.

The results of data analysis for 3 years, 2018-2020, show a fluctuating trend. In 2018 the use of TCM for TB examination was still limited by using the criteria for suspected RO TB based on the 2014 National TB Guidelines ${ }^{[4]}$. In the manual, it is still limited to 9 criteria for suspects that can be examined, namely; TB patients fail treatment Category 2; Category 2 treatment TB patients who do not convert after 3 months of treatment; TB patients who have a history of non-standard TB treatment and use quinolones and second-line injection drugs for at least 1 month; TB patients who failed category 1 treatment; Category 1 treatment TB patients who remained positive after 3 months of treatment; TB patients relapse (relapse), category 1 and category 2; TB patients who return after loss to follow-up (negligent treatment/default); Suspected TB who has a history of close contact with MDR TB patients); TB-HIV co-infected patients who do not respond to OAT.

Based on 2018 data, the number of tests carried out is still low, namely 21,646 suspects. The low number of inspections carried out was due to the lack of existing TCM machines at that time, namely 33 machines and the distribution of cartridges was still limited from the TB SubDirectorate so that inspection referrals were still limited. The examination is only more focused on finding $\mathrm{RO} \mathrm{TB}$ cases that already have a high risk of RO TB. In the 2020 WHO Global Report stated that the estimated number of TB RO cases was $2.4 \%$ of all new TB patients and 13\% of TB patients who had been treated with a total estimated incidence of RO TB cases of $8.8 / 100,000$ population. In addition, it is estimated that $3.3 \%$ of new TB patients and $17.7 \%$ of previously treated TB patients are drug-resistant TB patients ${ }^{[2]}$.

The results of the TCM examination from suspects who were included in the criteria found the number of patients diagnosed as TB RO as many as 394 cases and TB SO as many as 15,250 cases. Patients diagnosed as TB SO will continue with standard treatment at their respective health facilities, however, for patients who are diagnosed as TB RO patients, a referral to TB RO or MTPTRO services will be given to get a complete examination before being given standard treatment for TB RO. The management of OR TB is carried out with a patient-centred approach (PatientCentered Approach), namely TB treatment services that are more accessible to patients, so that services can be provided as close as possible to the patient.

The results of data analysis in 2019 showed an increase in TCM inspections in line with the increasing distribution of TCM machines to 46 machines. This machine has been distributed in hospitals to health centers in 10 regencies and the rest of the TCM machines are only in hospitals. The increase in examinations increased by more than $100 \%$ from the previous year, which was 57,834 cases. From the examination, 613 cases of RO TB were found and 44,542 cases of SO TB were found. The increasing findings of TB SO and TB RO cases were also due to the policy to conduct extensive TCM examinations for all TB suspects. This is in accordance with the Minister of Health Regulation No. 67 of 2016 concerning 
Tuberculosis Management which also states that the use of the TCM machine is not only for examining TB RO suspects but also for diagnosis for new patients. The expansion of TCM examinations for all TB suspects will speed up the process of finding TB SO and TB RO cases so that the chain of transmission can be decided earlier by providing standard TB treatment ${ }^{[5]}$.

Similar results were obtained in a study conducted by Nelly, et al, namely a spike in TCM examinations of more than $50 \%$ along with the increase in the number of TCM in Aceh Province ${ }^{[6]}$. This study also shows an increase in the use of TCM examinations to capture new cases by 1.5 times compared to the previous year and the results are strengthened by the increasing number of cases detected. In another study conducted in Denpasar City, the results of examination with TCM were higher in finding positive TB cases than microscopic examination with an increase in the number of TB positive cases by $14.3 \%{ }^{[7]}$.

Before the TCM machines were evenly distributed in 24 districts, the specimens were examined microscopically. This method has several weaknesses, namely having low sensitivity, not being able to determine drug sensitivity, and having different qualities because it is influenced by the skill level of the technician in carrying out the examination. In addition, the inspection process goes through several stages so that it takes 1-2 days and there is a high chance of environmental contamination of the specimens to be examined. Compared to microscopic, the TCM machine has several advantages, namely it can detect the presence of $M$. tuberculosis quickly within 2 hours, the sensitivity level of the tool reaches $98.3 \%$ and the specificity level reaches $99 \%$, can detect Rifampicin resistance.

TCM inspection data in 2020 showed a significant decrease after the COVID-19 pandemic with utilization of $39 \%$. A sharp decline in inspections occurred in April to December. The decline occurred in line with the low number of public visits to health facilities, especially primary health facilities. Data from Balitbangkes shows that $83.6 \%$ of puskesmas experienced a decrease in patient visits and $43 \%$ of puskesmas did not carry out posyandu service activities. In addition, there are restrictions on services for examining sputum specimens in several TCM laboratories because one of the requirements set is to ensure that the specimens sent are not from patients suffering from COVID-19 as evidenced by the presence of a TB suspect antigen test ${ }^{[8]}$. The impact of these problems causes delays in establishing a diagnosis which results in a high potential for transmission ${ }^{[9]}$.

\section{CONCLUSION}

The addition of the number of TCM can increase the case finding of TB SO and TB RO which is accompanied by strengthening the specimen referral network system, especially in areas with difficult transportation or remote areas so that the diagnosis of $\mathrm{TB}$, especially $\mathrm{TB}$ with Rifampicin resistance can be found early.

Acknowledgement: None

\section{Conflict of Interest: None}

\section{Source of Funding: None}

\section{Ethical Approval: Approved}

\section{REFERENCES}

1. Ditjen P2P, 2020. Strategi Nasional Penanggulangan Tuberkulosis di Indonesia Tahun 2020-2024. Kemenkes RI Jakarta.

2. WHO. Global Tuberculosis Report 2020. Genewa: World Health Organization 2020.

3. Ditjen P2P, 2020. Petunjuk Teknis Penatalaksanaan Tuberkulosis Resisten Obat di Indonesia. Kemenkes RI Jakarta.

4. Ditjen P2PL, 2014. Pedoman Nasional Pengendalian TB. Kemenkes RI Jakarta.

5. Ditjen P2PL 2016. Peraturan Menteri Kesehatan No. 67 Tahun 2016 tentang Penanggulangan Tuberkulosis. Kemenkes RI Jakarta. 
Andi Julia Junus et.al. Utilization of molecular quick test as an effort to accelerate case findings of multi drug resistant tuberculosis in South Sulawesi Province.

6. Nelly Marisa, dkk. 2020. Tes Cepat Molekuler sebagai Alat Diagnosis Tuberkulosis di Provinsi Aceh. Jurnal Medisiana Indonesia Vol. 9 No. 1

7. Novianti, dkk. 2019. Pemanfaatan Tes Cepat Molekuler (TCM) GeneXpert sebagai Alat Diagnostik TB Paru di RSUD Wangaya Kota Denpasar. Jurnal Ekologi Kesehatan Vol. 18 No. 3.

8. Dinas Kesehatan Provinsi Sulawesi Selatan, Laporan Tahunan Dinas Kesehatan Provinsi Sulawesi Selatan tahun 2020. Makassar. Dinas Kesehatan Provinsi Sulawesi Selatan.
9. Lolong D, Simarmata O, Herawati M, et al. 2018. Studi evaluasi deteksi kasus TBC dengan Tes Cepat Molekuler (TCM) di Indonesia.

How to cite this article: Junus AJ, Gafur A. Utilization of molecular quick test as an effort to accelerate case findings of multi drug resistant tuberculosis in South Sulawesi Province. Gal Int J Health Sci Res. 2021; 6(3): 31-37. DOI: https://doi.org/10.52403/gijhsr.20210706 